\title{
Long-term trends in trunk diameter and tree height growth in planted forests in the humid tropics of West Java, Indonesia
}

\author{
Motoshi Hiratsuka $^{1,2, *}$, Takeshi Toma ${ }^{3,4}$, Nina Mindawati ${ }^{5}$, Ika Heriansyah ${ }^{5}$ and Yasushi \\ MORIKAWA ${ }^{1}$ \\ Faculty of Human Sciences, Waseda University, 2-579-15 Mikajima, Tokorozawa, Saitama 359-1192, Japan. \\ ${ }^{2}$ Present address: Mitsubishi UFJ Research and Consulting Co., Ltd., Grand Central Tower 2-16-4, Konan, Minato-ku, Tokyo 108-8248, \\ Japan. \\ Center for International Forestry Research, P.O. Box 6596 JKPWB, Jakarta 10065, Indonesia. \\ ${ }^{4}$ Present address: Forestry and Forest Products Research Institute, P.O. Box 16 Tsukuba Norin Danchi, Tsukuba, Ibaraki 305-8687, Japan. \\ ${ }^{5}$ Forest and Nature Conservation Research and Development Center, P.O. Box 165 Bogor 16001, Indonesia. \\ * Corresponding author: Tel/Fax: +81-429-47-6817, e-mail: motoshi@ruri.waseda.jp
}

\begin{abstract}
Trunk diameter $(D, \mathrm{~cm})$ and tree height $(H, \mathrm{~m})$ growth curves were produced for 49 timber tree species from planted forests in West Java, Indonesia. Data were available covering a period of more than 40 years. The $D$ and $H$ of all trees of various ages were measured and coefficients of the Gompertz growth function were determined for each tree species. The tree species were then classified according to their wood production potential, on the basis of the relationship between their potential growth rate $k$, and asymptotic maximum carrying capacity $A$. The relationships between $k$ and $A$, for both $D$ and $H$ growth curves of the tree species investigated, were negatively correlated $(p<0.05)$. Tree species of the Dipterocarpaceae exhibited a variety of growth characteristics with respect to $D$. In contrast the $H$ growth characteristics for this family tended to be similar, with lower $k$ values and higher $A$ values than other tree species. These growth performance data for specific timber tree species will be useful to aid in the selection of tree species to plant, and in facilitating the establishment of forestry systems with long-term rotations (30 to 50 years) in the humid tropics.
\end{abstract}

Keywords: Growth curve, Long-term managed forest, timber tree species

\section{INTRODUCTION}

Worldwide, demand for timber from the tropics has been increasing since the late $20^{\text {th }}$ century. In Asia, China's import of $\operatorname{logs}$ increased to 7.6 million $\mathrm{m}^{3}$ (i.e., $60 \%$ of all consumer country log imports) in 2003 (ITTO, 2004) onwards as economic growth in recent years. India's imports of $\log$ also display an upward trend. Other developing countries in Asia continue to grow rapidly, with output increasing by $5.1 \%$ in 2003 and $5.6 \%$ in 2004 . With economic growth comes an increasing demand for wood products in these countries. To meet this demand, there is an urgent need to develop planted forests for wood production.

Indonesia is a one of the principal timber-producing countries in the world. In 2004, 30 million $\mathrm{m}^{3}$ of $\operatorname{logs}$ and 6.4 million $\mathrm{m}^{3}$ of plywood were produced (ITTO, 2004). However, Indonesia lost huge areas of forest in the last two decades of the $20^{\text {th }}$ century as a result of forest fires (Fatawi and Mori, 2000; Fuller and Fulk, 2001; Siegert and Hoffmann, 2000), illegal logging, forest conversion, unplanned agricultural expansion, political reformation, and social gaps.

Restoring degraded land by planting timber tree species is now considered to be essential from a number of perspectives: environmental protection, carbon sequestration, and continuing wood supply. In addition, planted forests might decrease the harvesting pressure on primary forests in the tropics (Fenning and Gershenzon, 2002) by providing an alternative source of timber. Thus, production of tropical timber in planted forests is important in order to satisfy the demand for the timber (Fredericksen and Putz, 2003; Sedjo, 2001). Hence, we need to make up the scenario of forest establishment system using timber tree species. However, there is a little information available on basic growth characteristics of such tree species in planted forests in the tropics (Hiratsuka et al. 2005).

In this study, we determined the growth 
characteristics of popular timber tree species using the coefficients of the Gompertz growth function. Data collected over 40 years from experimental forests in West Java, recording trunk diameter and tree height, were used. The results can be used in the selection of tree species and also to predict the growth of planted trees.

\section{MATERIAL AND METHODS}

\section{Study sites}

This data were collected from five experimental forests: Cikole, Cikampek, Carita, Dramaga, and Haurbentes, all belonging to the Forest Research and Development Agency, Ministry of Forestry of Indonesia (FORDA) and located in West Java, Indonesia (Fig. 1, Table 1). The annual rainfall and soil classification are presented in Table 1. All sites, except Cikole, can be described as lowland forest; Cikole is low mountain forest. Cikole was considered separately from the other four sites in our analysis. These forests were established between 1937 and 1955 in order to evaluate the growth characteristics, fruiting patterns, and silvicultural potential of dipterocarps and other exotic timber tree species (Masano and Alrasjid, 1991). The planted areas had been affected by wildfires and were covered with wild grass prior to planting. They were established using seeds and seedlings obtained from Sumatra, Kalimantan and the Bogor Botanical Garden in West Java. The seeds were planted into small pots in a canopied nursery and hurdling operation were carried out under the net shades. When saplings had reached a height of about $40 \mathrm{~cm}$, they were transplanted to one of the experimental forests.

Each forest comprised 0.25 ha $(50 \times 50 \mathrm{~m})$ trial plots. Initially, one or more tree species were planted in each plot. Saplings were planted at a spacing of 3 x $3 \mathrm{~m}(1,111$ trees $\left.\mathrm{ha}^{-1}\right)$ in most plots. Since replacement trees were planted if the original saplings died, each plot contained individuals of different ages. Thinning was not carried out in any of the experimental forests following their establishment. In 2003, many plots contained naturally regenerated trees, the parents of which were the planted trees. Of the dipterocarps, Shorea palembanica Miq., $S$. pinanga $\mathrm{R}$. Scheffer, and $S$. leprosula Miq. were frequently observed amongst the new generation and pioneer tree species were also regenerating in most plots.

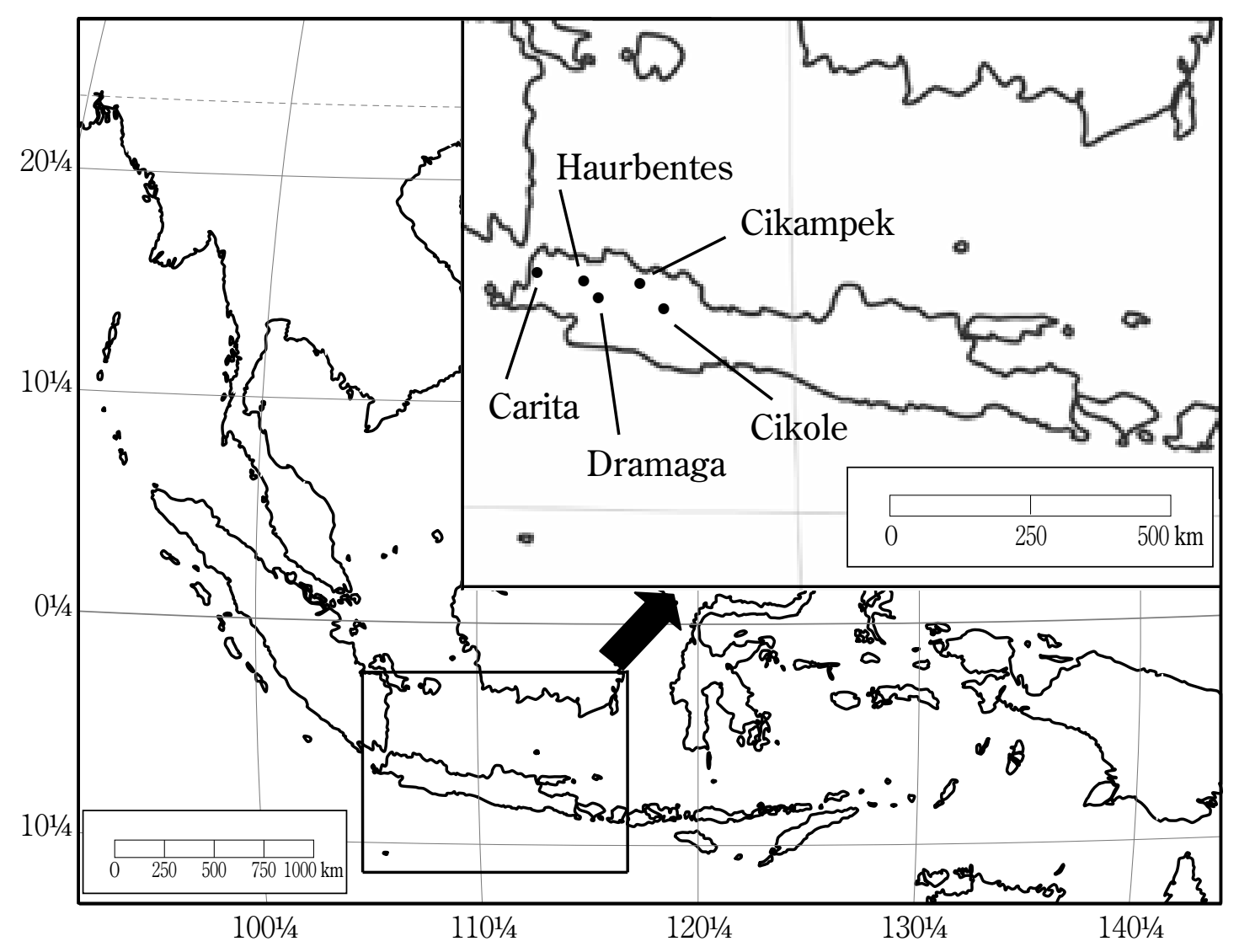

Fig. 1. Study sites in West Java, Indonesia. 
Table 1. General information about the five experimental forests in West Java, Indonesia.

\begin{tabular}{|c|c|c|c|c|c|}
\hline Site & Carita & Cikampek & Cikole & Dramaga & Haurbentes \\
\hline Latitude & $6^{\circ} 18^{\prime} \mathrm{S}$ & $6^{\circ} 25^{\prime} \mathrm{S}$ & $6^{\circ} 46^{\prime} \mathrm{S}$ & $6^{\circ} 33 ’ \mathrm{~S}$ & $6^{\circ} 33 ’ \mathrm{~S}$ \\
\hline Longitude & $105^{\circ} 50^{\prime} \mathrm{E}$ & $107^{\circ} 27^{\prime} \mathrm{E}$ & $107^{\circ} 39^{\prime} \mathrm{E}$ & $106^{\circ} 45^{\prime} \mathrm{E}$ & $106^{\circ} 26^{\prime} \mathrm{E}$ \\
\hline Altitude (m. asl) & 50 & 50 & 1,500 & 220 & 250 \\
\hline Rainfall $\left(\mathrm{mm} \mathrm{yr}^{-1}\right)$ & 2,102 & 1,796 & 2,996 & 3,552 & 4,276 \\
\hline Soil Classification & Alluvial & Latosol & Brown Alluvial & $\begin{array}{c}\text { Brown Reddish } \\
\text { Latosol }\end{array}$ & $\begin{array}{l}\text { Red Yellow } \\
\text { Podsolik }\end{array}$ \\
\hline Established year & 1955 & 1937 & 1954 & 1956 & 1940 \\
\hline Area (ha) & 50 & 45 & 40 & 60 & 100 \\
\hline Number of plot & 65 & 171 & 132 & 120 & 164 \\
\hline Main species & $\begin{array}{l}\text { Shorea sp., } \\
\text { Hopea } \mathrm{sp} .\end{array}$ & Hymenaea sp., & $\begin{array}{c}\text { Alnus sp., } \\
\text { Eucalyptus sp. }\end{array}$ & $\begin{array}{l}\text { Shorea sp., } \\
\text { Hopea } \text { sp. }\end{array}$ & $\begin{array}{l}\text { Shorea } \mathrm{sp} ., \\
\text { Hopea } \mathrm{sp} .\end{array}$ \\
\hline Number of investigated plots & 47 & 149 & 107 & 20 & 101 \\
\hline
\end{tabular}

\section{Field investigation}

A tree census has been conducted by FORDA in each plot at intervals of three to five years since one year after establishment. The latest census was conducted by the authors in all plots between July and October 2003. By 2003 , plots had been surveyed between one and sixteen times. Trunk diameter $1.3 \mathrm{~m}$ high above the ground $(D$, $\mathrm{cm}$ ) of all trees with a diameter of $10 \mathrm{~cm}$ or more and tree height $(H, \mathrm{~m})$ were recorded. For trees with a buttress over $1.3 \mathrm{~m}$ high, the diameter was measured $20 \mathrm{~cm}$ above the upper ridge of the buttress. Mean $D$ and $H$ for each tree species in each plot were calculated for each census.

There were 229 plots (57\%) where the basal area (BA, $\mathrm{m}^{2} \mathrm{ha}^{-1}$ ) of the trees planted originally accounted for more than $75 \%$ of the total BA of the plots in 2003. From those plots, we selected 49 timber tree species which had been surveyed at least seven times over more than 40 years. Planted tree species in Cikole were considered separately from the others, because Cikole is at a significantly higher altitude than the other sites.

The repeated tree censuses data from the 49 tree species was used to fit growth curves for $D$ and $H$ to the Gompertz growth function. We assumed that the mean $D$ and $H$ growth of each tree species followed the Gompertz growth function, expressed by the following equation:

$$
Y=A \cdot \exp [-b \cdot \exp (-k t)] \quad \text { (1) }
$$

where $Y$ represents $D$ or $H, A$ is the carrying capacity, $b$ is a coefficient depending on the initial $D$ or $H, k$ is the coefficient of growth, and $t$ is the stand age (years after planting). Values of $A$ and $k$ denote the asymptotic maximum $D$ or $H$ and the potential growth rate of each tree species, respectively. Therefore, $A$ and $k$ can be regarded as indices of the mature size and the growth rate, respectively, of each tree species in this study.

\section{RESULTS AND DISCUSSION}

The 49 tree species showed good correlation $(R=0.76$ to 1.00 for $D$ growth and $R=0.80$ to 1.00 for $H$ growth) with the Gompertz growth function (Appendix 1). Almost all tree species, especially members of the dipterocarps, showed no marked increase in $D$ or $H$ after the age of 30 to 40 years (Figs. 2 and 3). In primary forest in Indonesia, trees larger than those recorded in this study (130.5 $\mathrm{cm}$ trunk diameter at buttress height and $70.7 \mathrm{~m}$ tall) have been reported, but with no indication of their age (Yamakura et al. 1986). Unfortunately, we were unable to evaluate the difference in growth performance between primary forest and the experimental forests with respect to either site conditions or genetic analysis; such an investigation would be valuable.

Potential growth rate $k$ and the asymptotic maximum value $A$ for $D$ and $H$ growth curves were negatively correlated $(p<0.05)$ (Fig. 4$)$. Among the dipterocarps, the growth characteristics of $D$ were variable. The growth characteristics of $H$ tended to be similar, with lower $k$ values and higher $A$ values compared with other tree species. The relationship between bulk density $\left(\mathrm{kg} \mathrm{m}^{-3}\right)$ of tree species (data from the World Agroforestry Centre, 2007) and potential growth rate $k$ of the dipterocarps were also negatively correlated, but this was not significant.

The growth characteristics of the 49 tree species differed from each other (Appendix 1). Tree species could be roughly separated into $A$-type and $k$-type, according to the relationships between $A$ and $k$ for $D$ and $H$ growth. $A$-type species displayed a tendency towards a 

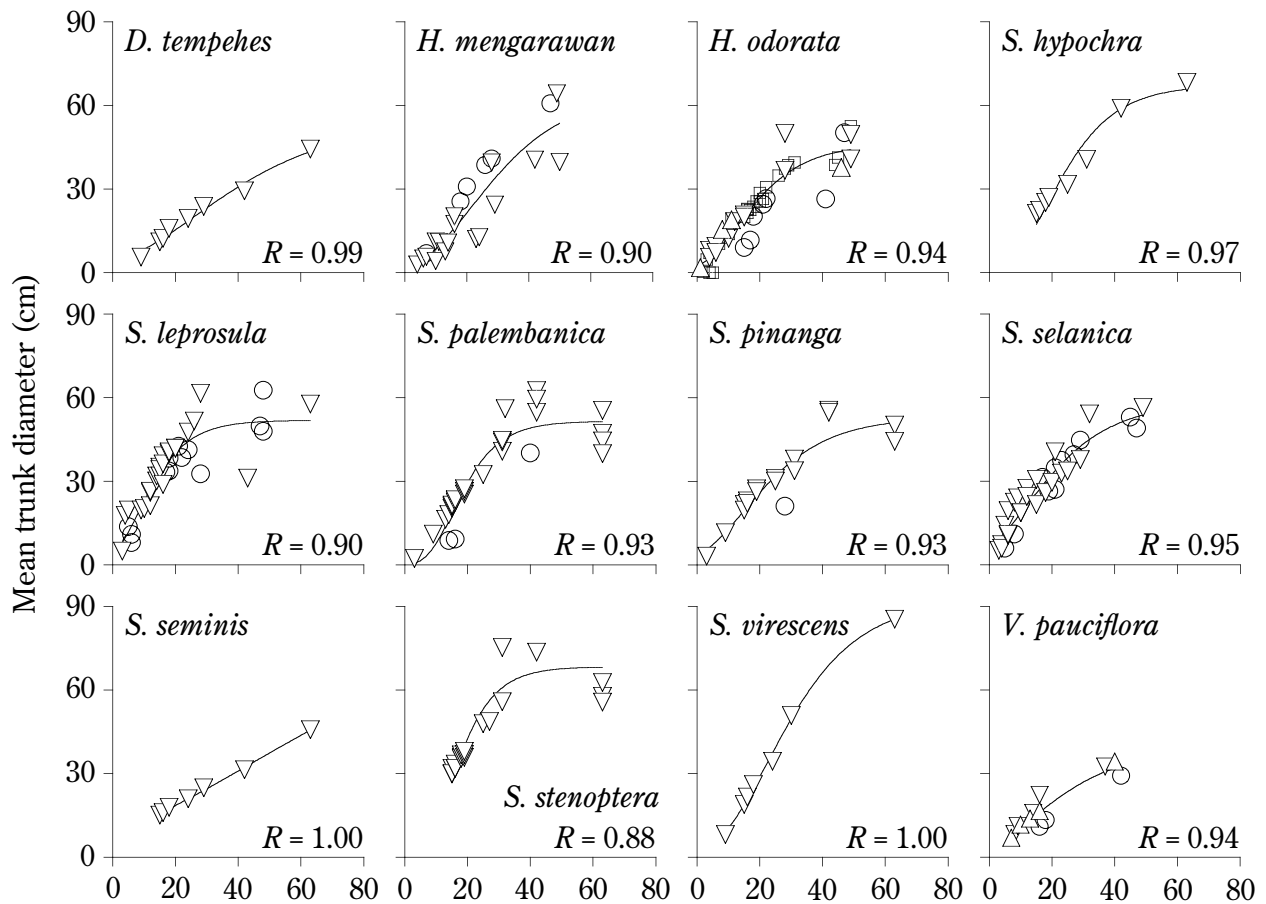

Age after planting (years)

Fig. 2. The relationships between age after planting (year) and mean trunk diameter (cm) according to the Gompertz growth function in dipterocarps in the Carita, Cilampek, Haurbentes, and Dramaga experimental forests. Legend: $\bigcirc$ Carita, $\square$ Cikampek, $\triangle$ Dramaga, and $\nabla$ Haurbentes.
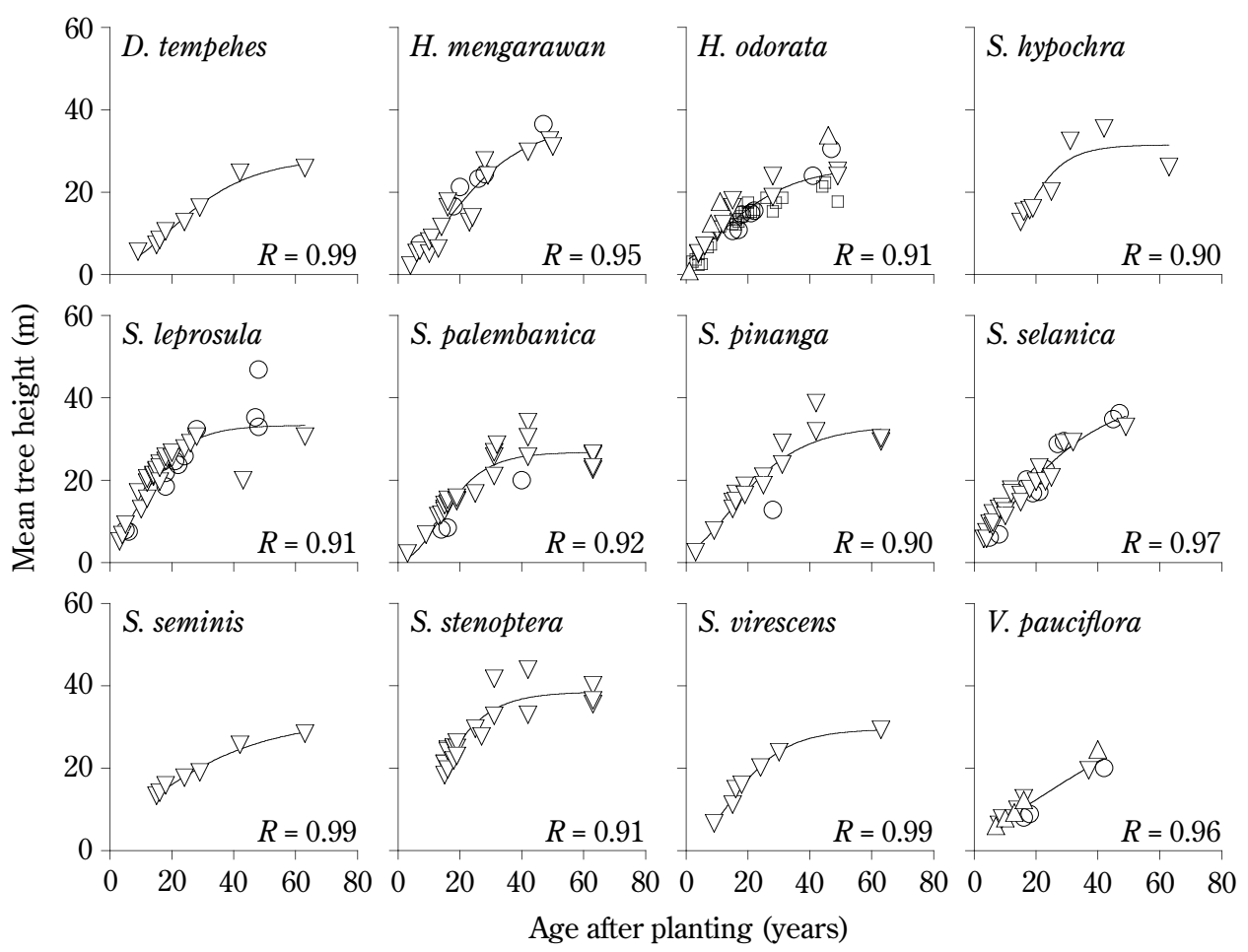

Fig. 3. The relationships between age after planting (year) and mean tree height (m) according to the Gompertz growth function in dipterocarps in the Carita, Cilampek, Haurbentes, and Dramaga experimental forests. Legend as for Fig. 2. 


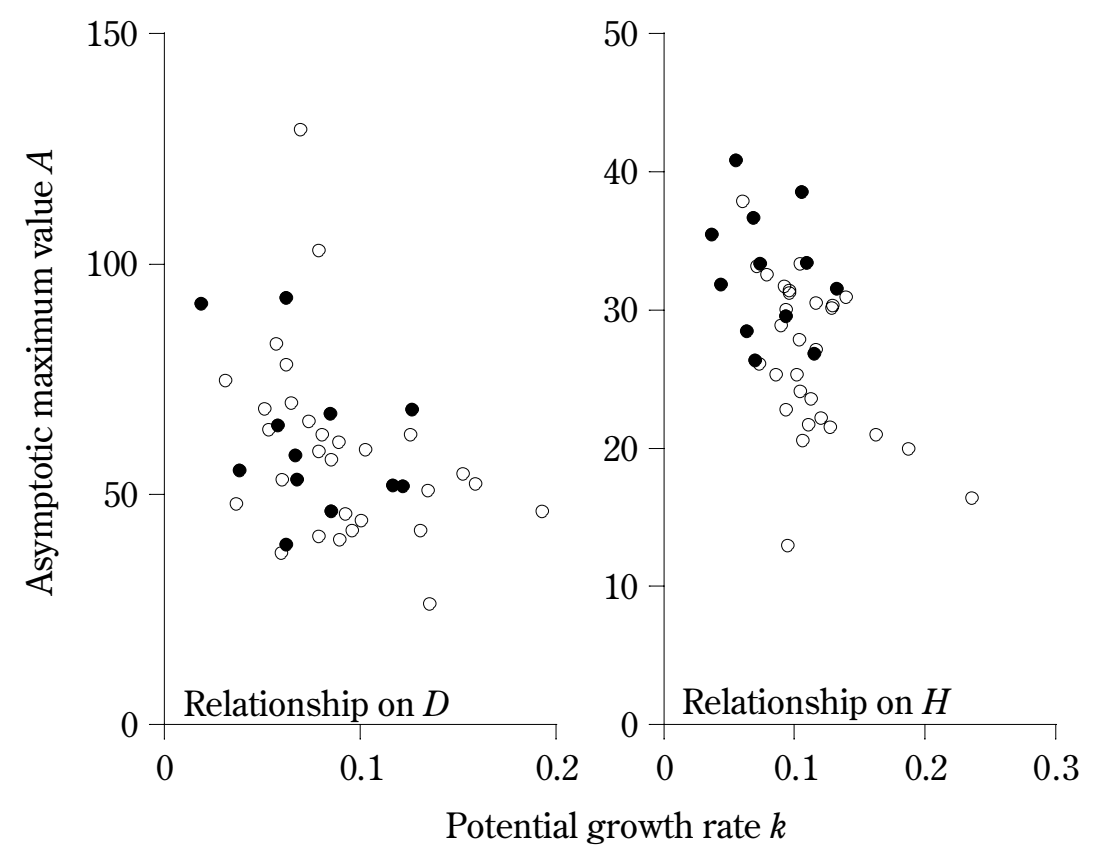

Fig. 4. The relationships between potential growth rate $k$ and asymptotic maximum value $A$ for trunk diameter $(D, \mathrm{~cm})$ and tree height $(H, \mathrm{~m})$ in the Carita, Cilampek, Haurbentes, and Dramaga experimental forests $(p<0.05)$. Closed circles indicate dipterocarps and open circles indicate other tree species.

large mature size $A$ despite a low $k$ value. $k$-type species displayed a tendency towards a high rate of $k$ despite a low $A$ value. Using this sort of information, appropriate tree species could be selected to fulfill specific requirements when planning new forest planting (e.g., when timber is required quickly, $k$ type species could be selected).

We suggest that data on the growth characteristics of each timber tree species are valuable for the preliminary selection of tree species to use in planted forests in the humid tropics, especially where timber production is the aim.

ACKNOWLEDGEMENTS This study was part of the 'Rehabilitation of Degraded Tropical Forest Ecosystems' project run by the Center for International Forestry Research (CIFOR) and Japan. It was also part of the 'Potential Carbon Accumulation Capacity in Commercial Timber Tree Plantation in Indonesia' project, a collaboration between CIFOR and FORDA and Waseda University, Japan. This study was financially supported, in part, by the Ministry of Environment, Japan (B-60: Development of Evaluation Model for Carbon Sink). We thank Prof. Masahiro Amano (Waseda University, Japan) for valuable comments. We express our special thanks to CIFOR and FORDA for their kind supports. We also thank the scientists and staff of CIFOR and FORDA for their encouragement.

\section{REFERENCES}

Fatawi, M. \& Mori, T. 2000. Description of forest and forestry in East Kalimantan. In: Rainforest ecosystems of East Kalimantan. (eds. Guhardja, E., Fatawi, M., Sutisna, M., Mori, T. \& Ohta, S.). Ecological Study, Vol. 140, Springer Tokyo, 4-12.

Fenning, T.M. \& Gershenzon, J. 2002. Where will the wood come from? Plantation forests and the role of biotechnology. Trends in Biotechnology, 20: 291-296.

Fredericksen, T.S. \& Putz, F.E. 2003. Silvicultural intensification for tropical forest conservation. Biodiversity and Conservation, 12: 1445-1453.

Fuller, D.D. \& Fulk, M. 2001. Burned area in Kalimantan, Indonesia mapped with NOAA-AVHRR and Landsat TM imagery. International Journal of Remote Sensing, 22: 691-697.

ITTO. 2004. Annual review and assessment of the world timber situation 2004. ITTO. available at ITTO's web site, http://www.itto.or.jp/. Cited in October 25, 2005.

Hiratsuka, M. Toma, T. Mindawati, N. Heriansyah, I. \& 
Morikawa, Y. 2005. Biomass of a man-made forest of timber tree species in the humid tropics of West Java, Indonesia. Journal of Forest Research, 10: 487-491.

Masano, \& Alrasjid, H. 1991. Planting trial of Shorea platyclados at Pasir Hantap experimental garden. BIOTROP Special Publication, 41: 471-477.

Sedjo, R.A. 2001. From foraging to cropping: the transition to plantation forestry, and implications for wood supply and demand. Unasylva, 204: 24-32.

Siegert, F. \& Hoffmann, A.A. 2000. The 1998 forest fire in East Kalimantan (Indonesia): a quantitative evaluation using high resolution, multitemporal ERS-2 SAR images and NOAA-AVHRR Hotspot Data. Remote Sensing of Environment, 72: 64-77.

World Agroforestry Centre. 2007. Wood density database. available from: http://www. worldagroforestrycentre.org/-sea/Products/ AFDbases/WD/Index.htm. Accessed 30 March 2007.

Yamakura, T. Hagihara, A. Sukardjo, S. \& Ogawa, H. 1986 Tree size in a mature dipterocarp forest stand in Sebulu, East Kalimantan, Indonesia. Southeast Asian Studies, 23: 452-478.

Received $13^{\text {th }}$ Jan. 2007

Accepted $22^{\text {nd }}$ June 2007 
Appendix 1. Coefficients of the growth equations for trunk diameter $(D, \mathrm{~cm})$ and tree height $(H, \mathrm{~m})$ from the Gompertz growth function, for each tree species in the Carita, Cilampek, Haurbentes, and Dramaga experimental forests.

\begin{tabular}{|c|c|c|c|c|c|c|c|c|c|c|c|}
\hline \multirow[t]{2}{*}{ Tree species } & \multirow[t]{2}{*}{ Family } & \multirow{2}{*}{$\begin{array}{l}\text { Age* } \\
\text { year }\end{array}$} & \multicolumn{4}{|c|}{$\begin{array}{l}\text { Coefficients } \\
\text { of growth equation on } D\end{array}$} & \multicolumn{4}{|c|}{$\begin{array}{l}\text { Coefficients } \\
\text { of growth equation on } H\end{array}$} & \multirow[t]{2}{*}{$\mathrm{BD}^{*}$} \\
\hline & & & $A$ & $b$ & $k$ & $R$ & $A$ & $b$ & $k$ & $R$ & \\
\hline Durio zibethinus & Bombacacea & 52 & 37.13 & 2.60 & 0.0602 & 0.98 & 21.67 & 2.62 & 0.111 & 0.98 & 570 \\
\hline Canarium schweinfurthii & Burseraceae & 65 & 57.50 & 2.93 & 0.0855 & 1.00 & 22.76 & 1.82 & 0.0943 & 0.98 & 360 \\
\hline Casuarina equisetifolia & Casuarinaceae & 43 & 41.95 & 1.96 & 0.0964 & 0.97 & 27.79 & 1.45 & 0.104 & 0.99 & 950 \\
\hline Maranthes corymbosa & Chrysobalanaceae & 65 & 78.02 & 3.04 & 0.0628 & 0.99 & 30.49 & 2.46 & 0.117 & 0.96 & 765 \\
\hline Terminalia arjuna & Combretaceae & 48 & 52.19 & 5.28 & 0.159 & 1.00 & 22.16 & 2.66 & 0.121 & 0.99 & 817 \\
\hline Terminalia kaernbachii & Combretaceae & 48 & 40.04 & 1.98 & 0.0897 & 0.95 & 20.97 & 1.49 & 0.163 & 0.98 & 520 \\
\hline Dipterocarpus tempehes & Dipterocarpaceae & 63 & 55.10 & 2.78 & 0.0391 & 0.99 & 28.41 & 3.35 & 0.0643 & 0.99 & 668 \\
\hline Hopea mengarawan & Dipterocarpaceae & 50 & 64.87 & 3.57 & 0.0586 & 0.90 & 36.65 & 3.05 & 0.0692 & 0.95 & 710 \\
\hline Hopea odorata & Dipterocarpaceae & 49 & 46.25 & 3.02 & 0.0855 & 0.94 & 26.29 & 2.06 & 0.0705 & 0.91 & 775 \\
\hline Shorea hypochra & Dipterocarpaceae & 63 & 67.29 & 4.87 & 0.0852 & 0.97 & 31.48 & 7.21 & 0.133 & 0.90 & 690 \\
\hline Shorea leprosula & Dipterocarpaceae & 63 & 51.88 & 2.66 & 0.117 & 0.90 & 33.36 & 2.39 & 0.110 & 0.91 & 583 \\
\hline Shorea palembanica & Dipterocarpaceae & 63 & 51.56 & 6.39 & 0.122 & 0.93 & 26.80 & 4.47 & 0.116 & 0.92 & 560 \\
\hline Shorea pinanga & Dipterocarpaceae & 63 & 53.04 & 2.79 & 0.0682 & 0.93 & 33.32 & 2.78 & 0.0740 & 0.90 & 468 \\
\hline Shorea selanica & Dipterocarpaceae & 49 & 58.36 & 2.26 & 0.0676 & 0.95 & 40.77 & 2.09 & 0.0555 & 0.97 & 485 \\
\hline Shorea seminis & Dipterocarpaceae & 63 & 91.16 & 2.34 & 0.0193 & 1.00 & 31.82 & 1.67 & 0.0445 & 0.99 & 905 \\
\hline Shorea stenoptera & Dipterocarpaceae & 63 & 68.32 & 6.01 & 0.127 & 0.88 & 38.50 & 3.13 & 0.106 & 0.91 & 575 \\
\hline Shorea virescens & Dipterocarpaceae & 63 & 92.43 & 4.06 & 0.0625 & 1.00 & 29.53 & 3.49 & 0.0942 & 0.99 & 470 \\
\hline Vatica pauciflora & Dipterocarpaceae & 42 & 38.88 & 2.39 & 0.0626 & 0.94 & 35.41 & 2.21 & 0.0371 & 0.96 & 520 \\
\hline Ricinodendron heudelotii & Euphorbiaceae & 50 & 46.16 & 3.16 & 0.193 & 0.96 & 21.52 & 1.95 & 0.128 & 0.93 & 570 \\
\hline Calophyllum soulattri & Guttiferae & 49 & 40.82 & 2.37 & 0.0791 & 0.99 & 20.52 & 2.06 & 0.107 & 1.00 & 360 \\
\hline Cinnamomum porrectum & Lauraceae & 41 & 45.58 & 2.35 & 0.0929 & 1.00 & 30.92 & 2.57 & 0.140 & 0.99 & 950 \\
\hline Enterolobium cyclocarpum & Leguminosae & 54 & 102.88 & 2.77 & 0.0791 & 0.96 & 30.01 & 1.88 & 0.0939 & 0.94 & 765 \\
\hline Hymenaea courbaril & Leguminosae & 65 & 63.92 & 2.10 & 0.0538 & 0.93 & 31.40 & 1.83 & 0.0968 & 0.86 & 817 \\
\hline Piptadenia peregrina & Leguminosae & 54 & 129.02 & 3.59 & 0.0698 & 0.97 & 30.31 & 2.53 & 0.130 & 0.94 & 520 \\
\hline Trachylobium verrucosum & Leguminosae & 64 & 50.67 & 4.18 & 0.135 & 0.98 & 23.55 & 2.67 & 0.113 & 0.90 & 545 \\
\hline Azadirachta excelsa & Meliaceae & 46 & 68.51 & 2.68 & 0.0515 & 0.90 & 33.10 & 2.06 & 0.0717 & 0.95 & 668 \\
\hline Azadirachta indica & Meliaceae & 50 & 26.10 & 5.32 & 0.136 & 0.98 & 12.93 & 2.07 & 0.0955 & 0.97 & 710 \\
\hline Cedrela odorata & Meliaceae & 64 & 53.03 & 1.93 & 0.0604 & 0.95 & 16.36 & 1.45 & 0.236 & 0.80 & 775 \\
\hline Chukrasia tabularis & Meliaceae & 64 & 65.83 & 3.24 & 0.0743 & 0.97 & 28.85 & 2.00 & 0.0902 & 0.99 & 690 \\
\hline Khaya anthotheca & Meliaceae & 53 & 82.65 & 2.70 & 0.0577 & 0.88 & 33.32 & 2.25 & 0.105 & 0.94 & 583 \\
\hline Khaya grandifoliola & Meliaceae & 54 & 62.89 & 3.31 & 0.0810 & 0.98 & 32.51 & 2.12 & 0.0794 & 0.95 & 560 \\
\hline Khaya senegalensis & Meliaceae & 48 & 62.89 & 3.48 & 0.126 & 0.98 & 27.10 & 2.00 & 0.117 & 0.96 & 468 \\
\hline Swietenia macrophylla & Meliaceae & 62 & 59.24 & 2.71 & 0.0792 & 0.92 & 24.09 & 2.32 & 0.105 & 0.96 & 485 \\
\hline Eucalyptus platyphylla & Myrtaceae & 45 & 41.97 & 2.95 & 0.131 & 0.96 & 19.93 & 1.52 & 0.188 & 0.91 & 955 \\
\hline Melaleuca quinquenervia & Myrtaceae & 40 & 74.63 & 1.95 & 0.0315 & 0.99 & 37.83 & 2.05 & 0.0610 & 0.99 & 725 \\
\hline Pinus caribaea & Pinaceae & 57 & 54.29 & 3.44 & 0.153 & 0.99 & 25.28 & 2.62 & 0.0865 & 0.91 & 410 \\
\hline Pinus kesiya & Pinaceae & 63 & 59.57 & 3.14 & 0.103 & 0.97 & 30.12 & 2.97 & 0.129 & 0.98 & 560 \\
\hline Pinus merkusii & Pinaceae & 64 & 47.80 & 1.11 & 0.0372 & 0.97 & 26.06 & 1.55 & 0.0733 & 0.96 & 505 \\
\hline Anthocephalus chinensis & Rubiaceae & 45 & 61.17 & 2.04 & 0.0896 & 0.99 & 31.69 & 1.63 & 0.0924 & 0.92 & 465 \\
\hline Pterygota alata & Sterculiaceae & 50 & 44.20 & 3.14 & 0.101 & 0.90 & 31.18 & 2.25 & 0.0967 & 0.92 & 720 \\
\hline Vitex cofassus & Verbenaceae & 65 & 69.64 & 2.69 & 0.0652 & 0.93 & 25.30 & 1.84 & 0.102 & 0.94 & 735 \\
\hline
\end{tabular}

* Tree age at the time of the most recent tree census

** Bulk density $\left(\mathrm{kg} \mathrm{m}^{-3}\right)$ of each tree species from the World Agroforestry Center (2007) 
Appendix 2. Coefficients of the growth equations for trunk diameter $(D, \mathrm{~cm})$ and tree height $(H, \mathrm{~m})$ from the Gompertz growth function for each tree species in the Cikole experimental forest.

\begin{tabular}{|c|c|c|c|c|c|c|c|c|c|c|c|}
\hline \multirow[t]{2}{*}{ Tree species } & \multirow[t]{2}{*}{ Family } & \multirow{2}{*}{$\begin{array}{l}\text { Age }^{*} \\
\text { year }\end{array}$} & \multicolumn{4}{|c|}{$\begin{array}{c}\text { Coefficients } \\
\text { of growth equation on } D\end{array}$} & \multicolumn{4}{|c|}{$\begin{array}{c}\text { Coefficients } \\
\text { of growth equation on } H\end{array}$} & \multirow[t]{2}{*}{$\mathrm{BD}^{* *}$} \\
\hline & & & $A$ & $b$ & $k$ & $R$ & $A$ & $b$ & $k$ & $R$ & \\
\hline Agathis borneensis & Araucariaceae & 48 & 44.04 & 3.79 & 0.114 & 1.00 & 31.30 & 3.53 & 0.121 & 0.97 & 470 \\
\hline Agathis dammara & Araucariaceae & 49 & 52.84 & 3.55 & 0.0733 & 0.97 & 34.26 & 2.48 & 0.0588 & 0.94 & 520 \\
\hline Widdringtonia nodiflora & Cupressaceae & 48 & 47.88 & 1.96 & 0.0575 & 0.99 & 19.49 & 1.31 & 0.0676 & 0.95 & 545 \\
\hline Cinnamomum porrectum & Lauraceae & 48 & 60.76 & 2.02 & 0.0426 & 0.99 & 43.34 & 1.94 & 0.0314 & 0.97 & 950 \\
\hline Khaya anthotheca & Meliaceae & 48 & 63.56 & 2.96 & 0.0565 & 0.99 & 38.43 & 2.43 & 0.0508 & 0.99 & 583 \\
\hline Eucalyptus deglupta & Myrtaceae & 49 & 48.15 & 1.72 & 0.0996 & 0.97 & 31.30 & 1.40 & 0.111 & 0.96 & 905 \\
\hline Eucalyptus maidenii & Myrtaceae & 44 & 35.09 & 2.23 & 0.0954 & 0.94 & 33.18 & 1.98 & 0.0680 & 0.93 & 575 \\
\hline Eucalyptus saligna & Myrtaceae & 49 & 48.33 & 1.64 & 0.0684 & 0.98 & 35.22 & 1.00 & 0.0584 & 0.96 & 900 \\
\hline Eucalyptus tereticornis & Myrtaceae & 48 & 58.89 & 2.69 & 0.0907 & 0.97 & 33.16 & 1.75 & 0.0836 & 0.99 & 765 \\
\hline Eucalyptus torelliana & Myrtaceae & 48 & 64.94 & 2.25 & 0.0711 & 0.99 & 40.13 & 3.60 & 0.108 & 0.94 & 853 \\
\hline Pinus caribaea & Pinaceae & 48 & 42.91 & 2.65 & 0.0789 & 0.88 & 25.28 & 2.62 & 0.0865 & 0.91 & 410 \\
\hline Pinus merkusii & Pinaceae & 47 & 57.80 & 2.37 & 0.0782 & 0.95 & 33.58 & 2.60 & 0.0851 & 0.92 & 505 \\
\hline
\end{tabular}

* Tree age at the time of the most recent tree census

** Bulk density $\left(\mathrm{kg} \mathrm{m}^{-3}\right)$ of each tree species from the World Agroforestry Center (2007) 